\title{
First record of sabellid and serpulid polychaetes from the Permian of Sicily
}

\author{
Rossana Sanfilippo, Antonietta Rosso, Agatino Reitano, and Gianni Insacco \\ Acta Palaeontologica Polonica 62 (1), 2017: 25-38 doi:http://dx.doi.org/10.4202/app.00288.2016
}

Some tubular fossils attributable to sabellids and serpulids, and a serpulid operculum are described for the first time from the Wordian to upper Permian "Pietra di Salomone", "Rupe di San Calogero", and "Rupe di San Benedetto" limestones (Sosio Valley, western Sicily, Italy). Tubes are attached to skeletons of sponges, crinoids, brachiopods and stromatoporoids. The material consists of about twenty incomplete tubes (attached and free portions) and includes some small tubes, ca. $0.2 \mathrm{~mm}$ wide, belonging to the sabellid Glomerula (with the species G. testatrix comb. nov. and G. gemmellaroi sp. nov.), the serpulid Filograna sp., and large-sized tubes, up to $3 \mathrm{~mm}$ wide, belonging to three newly described serpulids: Propomatoceros permianus sp. nov., "Serpula" distefanoi sp. nov., and Serpulidae sp. indet. They are triangular or circular in cross-sections, and display growth lines and/or ornamentations (keels or ribs) on their outer surfaces. Furthermore, an opercular cup referable to those assigned to the genus Pyrgopolon, is also described under the name $P$. gaiae sp. nov. All specimens show large secondary calcite crystals in their tubes, the original structure being biased by diagenesis. Material represents the first evidence of genuine calcareous tube-dwelling polychaetes from the Palaeozoic, and possibly so far unknown ancestral representatives of the families Sabellidae and Serpulidae. The tubeworm association together with the invertebrates upon which they settled, presumably lived in an exposed shallow- water palaeoenvironment, at the outer edge of a carbonate platform.

Key words: Polychaeta, Sabellidae, Serpulidae, operculum, tube, Palaeozoic, Sicily.

Rossana Sanfilippo [sanfiros@unict.it] and Antonietta Rosso [rosso@unict.it], Department of Biological, Geological and Environmental Sciences, University of Catania, Corso Italia 57, 95129 Catania, Italy. Agatino Reitano [tinohawk@yahoo.it ] and Gianni Insacco [g.insacco@comune.comiso.rg.it], Museo di Storia Naturale di Comiso, Via degli Studi 9, 97013 Comiso, Italy. 
This is an open-access article distributed under the terms of the Creative Commons

Attribution License (for details please see creativecommons.org), which permits unrestricted use, distribution, and reproduction in any medium, provided the original author and source are credited.

FaF 